\title{
EFFECT OF AEROBIC EXERCISE ON BLOOD PRESSURE IN PATIENTS WITH HYPERTENSION: A META-ANALYSIS
}

\author{
Khairunissa1), Didik Gunawan Tamtomon $^{2}$, Hanung Prasetya ${ }^{3)}$ \\ 1)Masters Program in Public Health, Universitas Sebelas Maret \\ 2)Faculty of Medicine, Universitas Sebelas Maret \\ ${ }^{3)}$ Health Polytechnics, Ministry of Health Surakarta
}

\begin{abstract}
Background: In recent years there has been increasing evidence that aerobic exercise is associated with blood pressure. Regular physical exercise reduces blood pressure and is broadly recommended by World Health Organization. A systematic review and metaanalysis was conducted to explore the effect of aerobic exercise on blood pressure in patients with hypertension.

Subjects and Method: A systematic review and meta analysis study was conducted by collecting articles from PubMed, Science Direct, Research Gate, and Google Scholar databases, that published from 2010 to 2020. Keywords used "aerobic exercise" OR "aerobic training" AND "blood pressure" AND hypertension OR hypertensive OR "patients with hypertension" AND "randomized controlled trial". Quantitative study was analyzed using Review Manager 5.3 (RevMan 5.3) software.

Results: A meta analysis from 11 randomized control trial (RCT) studies showed that aerobic exercise reduced systolic blood pressure $(\mathrm{SMD}=-0.93 ; 95 \% \mathrm{CI}=-1.33$ to -0.53 ; $\mathrm{p}<0.001)$ and diastolic blood pressure $(\mathrm{SMD}=-0.56 ; 95 \% \mathrm{CI}=-0.92$ to $-0.20 ; \mathrm{p}=$ 0.002).
\end{abstract}

Conclusion: Aerobic exercise reduces blood pressure in hypertensive patients.

Keywords: Aerobic exercise, blood pressure, hypertension, meta analysis

\section{Correspondence:}

Khairunissa. Masters Program in Public Health, Universitas Sebelas Maret. Jl. Ir. Sutami 36A, Surakarta 57126, Central Java. Email: khairunissahabibio2@gmail.com Mobile: 081779226622. 